\title{
Coverage for the cost of outpatient nursing procedures by the Unified Health System: a percentage analysis*
}

\author{
Cobertura do custo dos procedimentos de enfermagem ambulatoriais \\ pelo Sistema Único de Saúde: análise percentual \\ Cobertura del costo de los procedimientos ambulatorios de enfermería \\ por el Sistema Único de Salud: análisis porcentual
}

How to cite this article:

Sportello EF, Castilho V, Lima AFC. Coverage for the cost of outpatient nursing procedures by the Unified Health System: a percentage analysis. Rev Esc Enferm USP. 2021;55:e03692. doi: https://doi.org/10.1590/S1980-220X2019026803692

\author{
Elisabete Finzch Sportello ${ }^{1}$ \\ Valéria Castilho² \\ Antônio Fernandes Costa Lima ${ }^{2}$ \\ * Extracted from the thesis: "Cobertura do custo \\ dos procedimentos de enfermagem pelo Sistema \\ Único de Saúde no ambulatório de um hospital \\ Universitário”, Programa de Pós-Graduação \\ em Gerenciamento em Enfermagem, Escola de \\ Enfermagem, Universidade de São Paulo, 2019. \\ ${ }^{1}$ Universidade de São Paulo, Escola \\ de Enfermagem, Programa de Pós- \\ Graduação em Gerenciamento em \\ Enfermagem, São Paulo, SP, Brazil. \\ ${ }^{2}$ Universidade de São Paulo, Escola de \\ Enfermagem, Departamento de Orientação \\ Profissional, São Paulo, SP, Brazil.
}

\begin{abstract}
Objective: To analyze the percentage of the coverage of transfers from the Brazilian Unified Health System regarding nursing procedures conducted in the Outpatient facility of a University Hospital. Method: Quantitative, exploratory, descriptive case study. The sample for calculating the mean total direct costs was composed of non-participant observations of 656 procedures. The obtained costs were compared to transfers from the Unified Health System by multiplying the amount of procedures agreed upon by the unit cost in the Unified Table of Procedures in 2016 and 2017. Results: The Unified Health System transferred a percentage corresponding to $11.13 \%$ of the actual cost in 2016 and to $16.02 \%$ in 2017 . In these two years, transfer values covered only a mean of $13.4 \%$, resulting in a percentage difference in revenue significantly smaller than the actual cost. Conclusion: The higher the productivity of the performed procedures, the higher was the hospital deficit and, consequently, the higher were the costs not covered by the Unified Health System.
\end{abstract}

\section{DESCRIPTORS}

Ambulatory Care; Nursing Care; Costs and Cost Analysis; Cost Control; Health Care Costs; Unified Health System. 


\section{INTRODUCTION}

Funding system is one of the main problems faced by the Brazilian Unified Health System (Sistema Único de Saúde - SUS), being its weak spot. The instability of the federal budget dedicated to health puts the Brazilian health system at risk, compromising service quality, universal access, and integral care ${ }^{(1-4)}$.

In Brazil, public hospitals are key institutions in the health system, consuming up to $70 \%$ of public expenses. Federal transfers have been decreasing every year, aggravating the financial crisis of health institutions related to SUS ${ }^{(5-6)}$.

The hospital revenue policy in effect, via production per procedure, is particularly relevant for this discussion. The Health Reform has struggled to innovate them with epidemiological profiles criteria, searching for a coherence with health needs by region. Changes in primary care funding were achieved, i.e., transfers per capita, accounting for the principles of integrality and equity of SUS ${ }^{(7)}$. This revenue per procedure system in hospital care currently persists; this mercantile bias is understood as inherited from the exaggerated relation of service contracts and agreements between the private sector and the state through the National Institute of Medical Assistance of Social Security (Instituto Nacional de Assistência Médica da Previdência Social-INAMPS)(8).

From the 1990s onwards, university hospitals (UH) became part of the hospital network of SUS through contracts mediated by the State Health Offices (Secretarias Estaduais de Saúde-SES). In secondary and tertiary care, these contracts maintained revenue per procedure, creating and broadening funding issues.

Contracting is employed to formalize a relation between public health managers and the hospitals integrating SUS under their management through a formal instrument - the contract -, which is how financial transfer to health organizations for hospital procedures is conducted. Their values are included in the SUS Unified Table ${ }^{(6,9)}$.

Other hospitals of state universities have been playing a relevant role in providing care to SUS users. However, Brazil's financial crisis, in addition to policies on funding and $\mathrm{UH}$ maintenance by the universities, has worsened in recent years, causing important damage to the offering of health services to the population. Thus, in 2018, Universidade de São Paulo (USP) paid for $92.24 \%$ of USP's UH, whereas SES transferred only $7.76 \%$ of the budget used for complementing funding ${ }^{(10)}$.

Currently, UHs are evaluated and certified as Teaching Hospitals (TH). Contracting via the SUS Unified Table of Procedures does not guarantee the specificities and particularities of these institutions, whose role is not only meeting physical and quality goals, but are also essential in teaching, research, and innovative and excellent assistance.

Discussing the funding of a public $\mathrm{UH}$ - based mainly on nursing excellence -, precursor of the Nursing Assistance System, whose path is based on the integration of teaching and assistance is almost a professional legacy, relating to this scenario as a historical responsibility, even in face of the contradiction of productivism.
It is thus noticeable that legislation on HU funding by SUS management is broad, but inefficient to meet the objectives and needs of these institutions.

Cost management is indispensable for health institutions, especially for those which depend on transferences from SUS, since, when there is no control, services are agreed upon inefficiently. This management should be specific for each sector and a large share of the positive results should be reinvested in the institution itself, a consequence of the statements in many management actions dedicated to following, continuous review of established contracts, and resource maximization ${ }^{(5)}$.

Calculation of procedure costs and its comparison with the values of financial transfers from SUS aim at helping hospital managers negotiate and readjust contracting ${ }^{(11-12)}$.

Many studies comparing the values of transfers from SUS in face of the high cost of procedures also identified the real problem of underfinancing of public hospitals in which coverage of these values fall short of the actual values. This budget deficit, associated to an increase in users who rely exclusively on this system, intensifies the crisis and leads to poor care quality ${ }^{(5,11-13)}$.

The lack of financial resources compromises the limited physical, human, and operational structure available, as well as the quality of the provided services. In face of this, cost management seeks to guarantee that quality health services are continuously provided for a smaller price, with no risks for professionals and patients, contributing to the financial balance of these institutions. In this perspective, considering that the nursing team is responsible for a large share of the procedures, nurses are fundamental to manage the cost of care, seeking to adjust human, physical, and material resources while increasing the quality of care and promoting accessibility to patients/users ${ }^{(13-15)}$.

In face of this, this study sought to analyze the percentage of coverage of transfers from SUS related to nursing procedures conducted in an Outpatient facility in a UH in São Paulo city which has no system to fund the formulation of strategies, such as budget planning aimed at following the relation between cost and revenue of the provided health services.

\section{METHOD}

\section{Design OF STUdy}

This a quantitative, exploratory, descriptive, single-case study.

\section{Population}

The population comprised nursing procedures, among the multiple activities conducted in an Outpatient facility of a UH in São Paulo city, between January 2016 and December 2017, including: nursing consultation (NC); medication administration (routes: intramuscular - IM, subcutaneous - SC, oral - PO, sublingual - SL, ocular instillation, inhalation, venipuncture for administration of medication and solutions - EV), Unna's boot (UB); small (S), medium (M), and large (L) dressings; stitch removal; indwelling bladder catheterization (IDBC), intermittent bladder catheterization 
(IBC); cystostomy tube (CT) replacement; insertion of probe for enteral nutrition (PEN); gastrostomy tube (GT) replacement, colostomy bag replacement, capillary glycemia, and Blood Pressure (BP) and Heart Rate (HR) measurement.

\section{Data collection}

Initially, data collection was conducted through consultation of monthly management reports from the UH's Outpatient facility, as well as the values obtained from the Table of Procedures Management System (Sistema de Gerenciamento da Tabela de Procedimentos - SIGTAP) of SUS.

The non-probabilistic convenience sample used to establish the total mean direct cost (TMDC) corresponded to the opportunities of non-participant observation of 656 procedures between November 2017 and July 2018.

\section{Calculating the TMDC}

The TMDC was calculated by multiplying the time (as per chronometer) spent by nurses and nursing technicians/ auxiliaries (NT/NA) by the unit cost of the direct workforce (DWF) added to the cost of material and solutions ${ }^{(16)}$. The transfers from SUS were calculated by multiplying the number of procedures agreed upon by the transferred unit cost in the SIGTAP table ${ }^{(9)}$.

The unit cost of DWF per minute, based on mean salaries of the professional categories, considering a workload of 144 hours/month, corresponded to R $\$$ (BRL - Brazilian Reais) 2.25 for the category nurse and to $\mathrm{R} \$ 1.27$ for the category NT/NA. For calculating the mean cost of material and solutions, the mean unit cost paid by the $\mathrm{UH}$ in the last three purchases was used.

The measured costs from the sample of observed procedures were multiplied by the number of procedures conducted in 2016 and 2017 and compared to the values transferred by SUS. The continuous variables were described with position (mean) and scale (standard deviation - SD) statistics, in addition to the construction and analysis of $95 \%$ confidence intervals for the means.

\section{ETHICAL ASPECTS}

This research was approved by the Research Ethics Committee (REC) of EEUSP as a proposing institution in consolidated opinion number 2.157.170, and by the REC of the UH, as a collaborating institution, in consolidated opinion number 2.181.231. Both approvals occurred in 2017, in agreement with Resolution n. 466/12, by the National Health Council ${ }^{(17)}$.

\section{RESULTS}

In 2016 and 2017, 29,500 (100\%) patients were submitted to 84,046 nursing procedures conducted in the UH's Outpatient facility. Most patients were females (58.6\%); from the university community (55.0\%); with a mean age of 48.1 ( $\mathrm{SD}=25.3$ ) years; whose most frequent diagnosis were those of chapter XXI - Factors influencing health status and contact with health services (9,802-33.2\%); IX - Diseases of the circulatory system (4,371-14.8\%); XIII - Diseases of the musculoskeletal system and connective tissue $(2,786$ 9.4\%); and IV - Endocrine, nutritional and metabolic diseases $(2,75-9.3 \%)$.

From November 2017 to July 2018, fourteen nursing professionals were observed (six nurses and eight NT/NA) while performing the procedures. The mean age of these professionals corresponded to $52.86(\mathrm{SD}=9.05)$ years, with a mean work time in the $\mathrm{UH}$ of $26(\mathrm{SD}=8.05)$ years, mean work time in the Outpatient facility of $16.43(\mathrm{SD}=8.34)$ years, and mean education of $15.82(\mathrm{SD}=3.11)$ years. The mean education of the nurses was $18.00(\mathrm{SD}=2.45)$ years; all had one or more specializations (three in collective/public health, one in palliative care, one in nursing education, one in gerontology, one in pediatrics, and two in obstetrics); one of them had a master's in nursing education. The mean education for NT/NA was $13.63(\mathrm{SD}=2.06)$ years. One of the technicians was a nursing graduate.

The salary level of nursing professionals was observed to vary, which directly impacted the calculation of the mean costs of procedures. Thus, DWF was $\mathrm{R} \$ 2.25$ for nurses and $\mathrm{R} \$ 1.27$ for nursing technicians, due to the professional profile discussed.

Concerning the nursing procedures conducted in the Outpatient facility and agreed upon with the UH for 2016, SUS has reimbursed $\mathrm{R} \$ 76,884.12$ when it should have reimbursed $R \$ 568,884.56$, as indicated in Table 1 .

In Table 2, the calculated actual cost of non-agreed upon nursing procedures conducted in 2016 corresponded to $\mathrm{R} \$$ 122,193.69.

In Table 3, values reimbursed to UH by SUS for agreed upon nursing procedures in 2017 amounted to $\mathrm{R} \$ 96,100.11$. However, the actual cost was $\mathrm{R} \$ 485,693.91$, which represented a difference of $\mathrm{R} \$ 389,593.80$.

Table 1 - Distribution of the agreed upon nursing procedures regarding the unit cost of the SIGTAP* table, agreed upon and performed amounts per year, cost reimbursed by SUS, TMDC values**/SD*** of the procedures, actual costs in 2016, and difference between actual and reimbursed cost - São Paulo, SP, Brazil, 2019.

\begin{tabular}{|c|c|c|c|c|c|c|c|}
\hline Variables & $\begin{array}{l}\text { SIGTAP unit } \\
\text { cost* }^{*}\end{array}$ & $\begin{array}{c}\text { Amount } \\
\text { agreed upon }\end{array}$ & $\begin{array}{l}\text { Cost } \\
\text { reimbursed }\end{array}$ & $\begin{array}{c}\mathrm{TMDC}^{* *} \\
\text { values/ } \mathrm{SD}^{* * *}\end{array}$ & $\begin{array}{l}\text { Amount } \\
\text { performed }\end{array}$ & Actual cost & $\begin{array}{l}\text { Difference } \\
\text { between } \\
\text { actual cost and } \\
\text { reimbursement }\end{array}$ \\
\hline $\begin{array}{l}\text { High level consultations } \\
\text { (except physician) - } \\
\text { Nursing }\end{array}$ & 6.30 & 10,489 & $66,080.70$ & $30.48(26.77)$ & 10,489 & $319,704.72$ & $253,624.02$ \\
\hline $\begin{array}{l}\text { Dressing Grade II } \\
\text { (Medium) }\end{array}$ & 32.40 & - & - & $25.09(9.80)$ & 388 & $9,734.92$ & $9,734.92$ \\
\hline
\end{tabular}




\begin{tabular}{|c|c|c|c|c|c|c|c|}
\hline Variables & $\begin{array}{l}\text { SIGTAP unit } \\
\text { cost }^{*}\end{array}$ & $\begin{array}{c}\text { Amount } \\
\text { agreed upon }\end{array}$ & $\begin{array}{l}\text { Cost } \\
\text { reimbursed }\end{array}$ & $\begin{array}{c}\text { TMDC** } \\
\text { values/ } \mathrm{SD}^{* * *}\end{array}$ & $\begin{array}{c}\text { Amount } \\
\text { performed }\end{array}$ & Actual cost & $\begin{array}{l}\text { Difference } \\
\text { between } \\
\text { actual cost and } \\
\text { reimbursement }\end{array}$ \\
\hline $\begin{array}{l}\text { Dressing Grade II } \\
\text { (Large) }\end{array}$ & 32.40 & 24 & 777.60 & $56.91(24.35)$ & 355 & $20,203.05$ & $19,425.45$ \\
\hline $\begin{array}{l}\text { Dressing Grade II } \\
\text { (Unna's boot) }\end{array}$ & 32.40 & - & - & 120.7 (17.19) & 669 & $80,748.30$ & $80,748.50$ \\
\hline Intramuscular & 0.63 & 3,745 & $2,359.35$ & $6.15(1.52)$ & 3,745 & $23,031.75$ & $20,672.40$ \\
\hline Subcutaneous & 0.63 & 58 & 36.54 & $4.46(1.05)$ & 58 & 258.68 & 222.14 \\
\hline Sublingual & 0.63 & - & - & $3.35(0.99)$ & 0 & 0 & 0 \\
\hline Oral route & 0.63 & 3,548 & $2,235.24$ & $3.38(1.29)$ & 3,548 & $11,992.24$ & $9,757.00$ \\
\hline Ocular instillation & 0.63 & 1,858 & $1,170.54$ & $4.45(2.11)$ & 1,858 & $8,268.10$ & $7,097.56$ \\
\hline Total & ----- & ----- & $76,884.12$ & ---- & 2,7815 & $568,884.56$ & $492,000.44$ \\
\hline
\end{tabular}

Legend: *SIGTAP - Table of Procedures Management System of the Unified Health System **TMDC - Total Mean Direct Cost; ***SD - Standard Deviation.

Table 2 - Distribution of non-agreed upon nursing procedures regarding the unit cost of the SIGTAP * table, amount performed per year, values reimbursed by SUS, TMDC** values/SD*** of the procedures, actual costs in 2016 and difference between actual and reimbursed cost - São Paulo, SP, Brazil, 2019.

\begin{tabular}{|c|c|c|c|c|c|c|}
\hline Variables & $\begin{array}{l}\text { SIGTAP* unit } \\
\text { value }\end{array}$ & $\begin{array}{l}\text { Cost } \\
\text { reimbursed }\end{array}$ & $\begin{array}{l}\text { TMDC** } \\
\text { values/ } \\
\text { DP*** }\end{array}$ & $\begin{array}{c}\text { Amount } \\
\text { performed }\end{array}$ & Actual cost & $\begin{array}{l}\text { Difference between } \\
\text { actual cost and } \\
\text { reimbursement }\end{array}$ \\
\hline Dressing Grade I (Small) & 0.00 & 0.00 & $13.76(3.88)$ & 1,825 & $25,112.00$ & $25,112.00$ \\
\hline Nasoenteral tube insertion & 28.00 & 0.00 & $\begin{array}{c}83.27 \\
(19.17)\end{array}$ & 32 & $2,664.64$ & $2,664.64$ \\
\hline Inhalation & 0.00 & 0.00 & $4.82(1.81)$ & 539 & $2,597.98$ & $2,597.98$ \\
\hline Capillary Glycemia & 0.00 & 0.00 & $6.42(1.83)$ & 187 & $1,200.54$ & $1,200.54$ \\
\hline Stitch removal & 0.00 & 0.00 & $14.91(6.40)$ & 2,150 & $32,056.50$ & $32,056.50$ \\
\hline Intermittent bladder catheterization & 0.00 & 0.00 & $27.12(1.93)$ & 114 & $3,091.68$ & $3,091.68$ \\
\hline Indwelling bladder catheterization & 0.00 & 0.00 & $57.65(8.94)$ & 328 & $18,909.20$ & $18,909.20$ \\
\hline Cystostomy tube replacement & 0.00 & 0.00 & $\begin{array}{c}69.45 \\
(18.47)\end{array}$ & 19 & $1,319.55$ & $1,319.55$ \\
\hline gastrostomy tube replacement & NA & 0.00 & $\begin{array}{l}108.74 \\
(19.49)\end{array}$ & 59 & $6,415.66$ & $6,415.66$ \\
\hline Colostomy bag replacement & 0.00 & 0.00 & $\begin{array}{c}53.65 \\
(19.47)\end{array}$ & 0 & & \\
\hline Blood pressure and heart rate measurement & 0.00 & 0.00 & $2.86(0.64)$ & 10,079 & $28,825.94$ & $28,825.94$ \\
\hline Total & ----- & 0.00 & ----- & 15,332 & $122,193.69$ & $122,193.69$ \\
\hline
\end{tabular}

Legend: *SIGTAP - Table of Procedures Management System of the Unified Health System; ** TMDC - Total Mean Direct Cost -; *** SD - Standard Deviation

Table 3 - Distribution of agreed upon nursing procedures regarding the unit cost of SIGTAP $*$ table, agreed upon and performed amounts per year, values reimbursed by SUS, values of TMDC** / SD *** of the procedures, actual costs in 2017, and difference between actual and reimbursed cost - São Paulo, SP, Brazil, 2019.

\begin{tabular}{|c|c|c|c|c|c|c|c|}
\hline Variables & $\begin{array}{l}\text { SIGTAP* } \\
\text { unit value }\end{array}$ & $\begin{array}{c}\text { Amount } \\
\text { agreed } \\
\text { upon }\end{array}$ & $\begin{array}{l}\text { Cost } \\
\text { reimbursed }\end{array}$ & $\begin{array}{c}\text { TMDC }^{* *} \\
\text { value / } \mathrm{DP}^{* * *}\end{array}$ & $\begin{array}{l}\text { Amount } \\
\text { performed }\end{array}$ & Actual cost & $\begin{array}{l}\text { Difference between } \\
\text { actual cost and } \\
\text { reimbursement }\end{array}$ \\
\hline $\begin{array}{l}\text { High level consultations } \\
\text { (except physician) - } \\
\text { Nursing }\end{array}$ & 6.30 & 7,651 & $48,201.30$ & $30.48(26.77)$ & 7,651 & $233,202.48$ & $185,001.18$ \\
\hline $\begin{array}{l}\text { Dressing Grade II } \\
\text { (Medium) }\end{array}$ & 32.40 & 604 & $19,569.60$ & $25.09(9.80)$ & 604 & $15,154.36$ & $-4,415.24$ \\
\hline Dressing Grade II (Large) & 32.40 & 625 & $20,250.00$ & $56.91(24.35)$ & 625 & $35,568.75$ & $15,318.75$ \\
\hline $\begin{array}{l}\text { Dressing Grade II (Unna's } \\
\text { boot) }\end{array}$ & 32.40 & 602 & $19,504.80$ & $120.7(17.19)$ & 602 & $72,661.40$ & $53,156.60$ \\
\hline Intramuscular & 0.63 & 3,458 & $2,178.54$ & $6.15(1.52)$ & 3,458 & $21,266.70$ & $19,088.16$ \\
\hline Subcutaneous & 0.63 & 70 & 44.10 & $4.46(1.05)$ & 70 & 312.20 & 268.10 \\
\hline Sublingual & 0.63 & 503 & 316.89 & $3.35(0.99)$ & 503 & $1,685.05$ & $1,368.16$ \\
\hline Oral route & 0.63 & 2,128 & $1,340.64$ & $3.38(1.29)$ & 2,128 & $7,192.64$ & $5,852.00$ \\
\hline
\end{tabular}




\begin{tabular}{|c|c|c|c|c|c|c|c|}
\hline \multicolumn{8}{|l|}{...continuation } \\
\hline Variables & $\begin{array}{l}\text { SIGTAP* } \\
\text { unit value }\end{array}$ & $\begin{array}{l}\text { Amount } \\
\text { agreed } \\
\text { upon }\end{array}$ & $\begin{array}{c}\text { Cost } \\
\text { reimbursed }\end{array}$ & $\begin{array}{c}\mathrm{TMDC}^{* *} \\
\text { value / } \mathrm{PP}^{* * *}\end{array}$ & $\begin{array}{c}\text { Amount } \\
\text { performed }\end{array}$ & Actual cost & $\begin{array}{l}\text { Difference between } \\
\text { actual cost and } \\
\text { reimbursement }\end{array}$ \\
\hline Ocular instillation & 0.63 & 1,285 & 809.55 & $4.45(2.11)$ & 1,285 & $5,718.25$ & $4,908.70$ \\
\hline Endovenous & 0.63 & 6,563 & $4,134.69$ & $14.16(5.37)$ & 6,563 & $92,932.08$ & $88,797.39$ \\
\hline Total & ----- & ----- & $96,100.11$ & ----- & 23,489 & $485,693.91$ & $389,593.80$ \\
\hline
\end{tabular}

Legend: *SIGTAP - Table of Procedures Management System of the Unified Health System; ** TMDC - Total Mean Direct Costs; *** SD - Standard Deviation

The actual cost of procedures not agreed upon in 2017 was equivalent to $R \$ 114,304.85$ (Table 4).

Table 5 demonstrates that, in 2016 and 2017, the mean percentage of reimbursed values (agreed upon nursing procedures) was equivalent to $13.4 \%$ of the calculated costs for performed nursing procedures (including those not agreed upon) (86.6\%).

Table 4 - Distribution of nursing procedures not agreed upon regarding the unit cost of the SIGTAP * table, amount performed per year, values reimbursed by SUS, values of TMDC** / SD *** of the procedures, actual cost in 2017, and difference between actual and reimbursed cost - São Paulo, SP, Brazil, 2019.

\begin{tabular}{|c|c|c|c|c|c|c|}
\hline Variables & $\begin{array}{l}\text { SIGTAP* } \\
\text { unit value }\end{array}$ & $\begin{array}{c}\text { Reimbursed } \\
\text { value } R \$ / \text { year }\end{array}$ & $\begin{array}{l}\text { TMDC** value } \\
\text { / DP*** }\end{array}$ & $\begin{array}{c}\text { Amount performed/ } \\
\text { year }\end{array}$ & $\begin{array}{l}\text { Actual Cost } \\
\mathbf{R} \$ / \text { year }\end{array}$ & $\begin{array}{l}\text { Difference between } \\
\text { actual cost and } \\
\text { reimbursement }\end{array}$ \\
\hline Dressing Grade I (Small) & 0.00 & 0.00 & $13.76(3.88)$ & 1,033 & $14,214.08$ & $14,214.08$ \\
\hline $\begin{array}{l}\text { Nasoenteral tube } \\
\text { insertion }\end{array}$ & 28.00 & 0.00 & $83.27(19.17)$ & 24 & $1,998.48$ & $1,998.48$ \\
\hline Inhalation & 0.00 & 0.00 & $4.82(1.81)$ & 350 & $1,687.00$ & $1,687.00$ \\
\hline Capillary Glycemia & 0.00 & 0.00 & $6.42(1.83)$ & 212 & $1,361.04$ & $1,361.04$ \\
\hline Stitch removal & 0.00 & 0.00 & $14.91(6.40)$ & 2,066 & $30,804.06$ & $30,804.06$ \\
\hline $\begin{array}{l}\text { Intermittent bladder } \\
\text { catheterization }\end{array}$ & 0.00 & 0.00 & $27.12(1.93)$ & 41 & $1,111.92$ & $1,111.92$ \\
\hline $\begin{array}{l}\text { Indwelling bladder } \\
\text { catheterization }\end{array}$ & 0.00 & 0.00 & $57.65(8.94)$ & 259 & $14,931.35$ & $14,931.35$ \\
\hline $\begin{array}{l}\text { Cystostomy tube } \\
\text { replacement }\end{array}$ & 0.00 & 0.00 & $69.45(18.47)$ & 34 & $2,361.30$ & $2,361.30$ \\
\hline $\begin{array}{l}\text { gastrostomy tube } \\
\text { replacement }\end{array}$ & NA & 0.00 & $108.74(19.49)$ & 52 & $5,654.48$ & $5,654.48$ \\
\hline $\begin{array}{l}\text { Colostomy bag } \\
\text { replacement }\end{array}$ & 0.00 & 0.00 & $53.65(19.47)$ & 40 & $2,146.00$ & $2,146.00$ \\
\hline $\begin{array}{l}\text { Blood pressure and heart } \\
\text { rate measurement }\end{array}$ & 0.00 & 0.00 & $2.86(0.64)$ & 13,299 & $38,035.14$ & $38,035.14$ \\
\hline Total & 0.00 & 0.00 & ------ & 17,410 & $114,304.85$ & $114,304.85$ \\
\hline
\end{tabular}

Table 5 - Distribution of reimbursed costs for nursing procedures in 2016 and 2017, actual cost, and reimbursement difference - São Paulo, SP, Brazil, 2019.

\begin{tabular}{lcccccc}
\hline Year & Reimbursed value & $\%$ & Actual cost & $\%$ & Reimbursement difference & $\%$ \\
\hline 2016 & $76,884.12$ & 11.13 & $691,078.25$ & 100 & $614,194.13$ & 88.87 \\
2017 & $96,100.11$ & 16.02 & $599,998.76$ & 100 & $503,898.65$ & 83.98 \\
\hline Total & $\mathbf{1 7 2 , 9 8 4 . 2 3}$ & $\mathbf{1 3 . 4 0}$ & $\mathbf{1 , 2 9 1 , 0 7 7 . 0 1}$ & $\mathbf{1 0 0}$ & $\mathbf{1 , 1 1 8 , 0 9 2 . 7 8}$ & $\mathbf{8 6 . 6 0}$ \\
\hline
\end{tabular}

\section{DISCUSSION}

This research verified the percentual of coverage of transfers by SUS related to the costs of nursing procedures conducted in the Outpatient facility and calculated the difference between actual cost and the reimbursed value. For such, other TMDCs of performed procedures agreed upon and not agreed upon with SES were analyzed.

This showed that SUS should have reimbursed in 2016 a total of $\mathrm{R} \$ 691,078.25$, out of which $\mathrm{R} \$ 568,884.56$ referred to procedures agreed upon and $\mathrm{R} \$ 122,193.68$ to those not agreed upon. However, only $\mathrm{R} \$ 76,884.12$ were reimbursed, corresponding to a transfer deficit of $\mathrm{R} \$ 614,194.13$. In 2017, $R \$ 599,998.76$ should have been reimbursed, $R \$ 485.693,91$ of which dedicated to procedures agreed upon and R\$ $114,304.85$ to those not agreed upon. However, SUS reimbursed only R\$ 96,100.11, leaving a $\mathrm{R} \$ 503,898.65$ deficit.

The percentage for coverage by SUS of performed nursing procedures was $11.13 \%$ in 2016 and $16.02 \%$ in 2017, which was insufficient to cover the values spent by the hospital. In these two years, the financial deficit amounted to $\mathrm{R} \$$ $1,118,092.78$ ( $86.60 \%$ of the calculated cost). 
The values of the Unified Table of SUS must be updated to become closer to the calculated costs for hospital procedures which have aggregated value, the transfer values for procedures in the Table - however, with no corresponding value - must be established, and procedures conducted by the hospital and not yet agreed upon must be included in the contract with SES.

In addition, the procedures small dressing (grade I), stitch removal, IDBC, IBC, CT replacement, GT replacement, colostomy bag replacement, $\mathrm{PEN}$ insertion, inhalation, capillary glycemia, and BP and HR measurement were performed, generating costs for the $\mathrm{UH}$, but were either not agreed upon or, despite being in the SIGTAP table and being conducted in the UH, presented no established transfer values.

The mean direct cost of material and/or solutions consumption was prevalent in the composition of TMDC for procedures UB, PEN insertion, and GT replacement.

The mean direct cost with nurse and NT/NA DWF was the variable with the highest impact on the composition of TMDC for procedures stitch removal, dressings, colostomy bag replacement, capillary glycemia, medication administration: IM, PO, SL, SC, inhalation, ocular instillation, EV, BP and HR measurement, IDBC, IBC, CT replacement, and $\mathrm{NC}$; the last four procedures are exclusive to nurses.

In a study conducted in a public TH (Teaching Hospital) on the cost of procedures performed by the nursing team, the cost of material was found to be superior to that of DWF in the $\mathrm{TDMC}^{(18)}$. Such results diverge from those presented in this research, in which the DWF cost was prevalent for most procedures.

In a 2012 study on the direct cost of installation, maintenance, and shut-down of patient-controlled analgesia pumps by nurses in a TH, the TMDC for this procedure was observed to be $R \$ 223.40$, with a significant impact of material and solutions in its composition. This nursing procedure is also not included in the SIGTAP table, with no financial transfer from SUS, which entails thus budget deficits for this institution ${ }^{(19)}$.

The expenses with human resources and material account for an increase in the cost of public and private hospitals, ranging from $35 \%$ to $45 \%$ of the total budget, with a possibility of increasing it in accordance with the inefficiency of material management systems; these may consume $23 \%$ to $30 \%$ of this budget ${ }^{(20)}$.

The individual costs of procedures are the basis for the financial management of health units and, without the budget dimension, any attempt at improving the process of negotiation with SES is impossible ${ }^{(11)}$.

A study conducted in a public hospital in Belo Horizonte concluded that SUS revenue is insufficient to cover the cost for its procedures, covering only $30 \%$ of the actual costs ${ }^{(21)}$.

A study conducted in a hospital in Porto Alegre that has an agreement with SUS, by analyzing factors that impact the actual costs of procedures related to cerebrovascular accidents, verified that the deficit in transfers by SUS to cover these costs was $33 \%$ of the actual value paid by the institution. It concluded that the current model for revenue of services provided to SUS partnership, based on remuneration per procedure, and the values of the SIGTAP table of SUS, are out of phase with the actual costs ${ }^{(22)}$.

Difficulties related to patient treatment due to underfunding, which compromises access, may be noticed also concerning treatment of people with chronic wounds such as pressure injury, vascular ulcers, and complications from Diabetes Mellitus (DM) treated in Outpatient facilities and public services ${ }^{(23)}$.

A study on procedures for limb amputation due to DM lesions verified that SUS transfer was 3.6 times smaller than the cost paid by the hospital to perform the amputations. The worry with the growing costs in the health sector imposes that public hospitals resort to all management and administrative tools available, seeking economic balance and maintenance of health services in favor of the population, with the maximum possible efficiency ${ }^{(13)}$.

Studies on the implementation of a cost management system in Santas Casas de Misericórdia de São Paulo showed that revenues covered only $30 \%$ of actual costs for the performed procedures ${ }^{(24)}$.

In 2016, a study analyzed the coverage of cost for coronary artery bypass surgery by SUS in São Paulo. The mean transfer corresponded to $48.66 \%$ of the total mean cost, with a $51.34 \%$ deficit, showing that the transfer covered less than half of the total mean cost for this procedure. This indicated that the tendency is for increasingly negative revenues to cause serious financial problems to institutions, which reduce the number of services in order not to accumulate more debt and loss, damaging patient care. Such study reports that the tendency for these institutions is to decrease the number of services in agreement with SUS to equate budget deficits by negotiating other means of financial sustainability, such as private and health plan services ${ }^{(5)}$.

Underfunding is one of the barriers for equal quality access of patients to institutions with contracts with SUS. Hospitals face the challenge of underfunding in a setting of political and financial crisis with reduced capacity for State action, which makes health services' actions in accordance with the premises of a unified and universal system even more difficult ${ }^{(25)}$.

The current revenue model of services with agreement with SUS, based on remuneration per procedure and values in a unified table, is out of phase with the actual costs of the institutions ${ }^{(22)}$.

Health institutions must develop studies on the costs of performed procedures to support negotiation and to demand higher transfers from SUS, as well as sensitizing workers concerning rational use of resources, especially materials. The importance of understanding the management of hospital consumption materials and analyzing care processes and associated costs to minimize and/or eliminate waste is thus emphasized ${ }^{(26)}$.

The values for procedure costs found in this study diverge highly from the values in the Unified SUS Table. The fact that "the distance found between procedure cost and the values in such table must lead managers and researchers to think and put efforts on investigation of a 
more appropriate form of system funding for SUS providers"(27) is emphasized.

This fact is criticized in many studies on forms of funding and cost-effectivity of procedures performed in health services and is related to discussions on financial crises, both in public and private hospitals, national and international, which seek new forms of funding and quality, focused on the epidemiological, economic, social, and cultural characteristics of each country and its regions ${ }^{(27-30)}$.

Another issue to be discussed and critically reflected upon, concerning funding of procedures performed by SUS, is the workings of the hierarchization of health services. The population must have guaranteed access to appropriate services at the right time for their health-disease process to be evaluated and ideally followed, avoiding aggravation and offering appropriate services.

The responsibility for providing health services must lie on the three care levels, i.e., primary, secondary, and tertiary, with appropriate forms of management, organization, and planning. Consequently, patient flow should be organized to work harmonically and bear results for assistance, in accordance with the needs of each population, in an efficient manner, with improvements in resolution and no damage to patients and institutions related to the health system ${ }^{(8)}$.

Primary health care is the start of attendance, whose main objective is preventing diseases, treating simple aggravations, and forwarding severe cases to other complexity levels. Its duty is caring for and solving a large share of the population's health problems, in addition to organizing the flow of services in the health network, reserving the access to higher complexity care levels for those who require them. In secondary attention, medium complexity procedures are performed. To receive care in this level, patients need to be forwarded by the basic attention services ${ }^{(8)}$.

The non-reimbursable costs $(\mathrm{R} \$ 0.00)$ found in Table 4 refer to some of the procedures which should be performed in primary care, not in secondary care.

The integration of care levels is a challenge, considering the principle of integrality in health care. The reference and counter-reference system has failed because papers cannot respond for service articulation. The forms of articulation and interface among institutions might be improved through human initiative supported by information technology.

Procedure values in the SUS Unified Table do not account for care quality, reinforcing the production character of nursing. Such values are subsumed as in the immaterial and interactive process. In sum, mercantilization has consumed the sense of humanization, determining the direction of care.

The political and economic crises lived for years in Brazil cannot undermine the health system or the rights to universal and integral access to this system by the population. For such, elaborating and tracking health indexes, guaranteeing that any adverse effects are observed and avoided, is an imperative ${ }^{(31)}$.

\section{CONCLUSION}

From the calculated costs of nursing procedures performed in the UH's Outpatient facility, which was this study's scenario, SUS should have reimbursed in 2016 the amount of $\mathrm{R} \$ 691,078.25$, out of which $\mathrm{R} \$ 568,884.56$ refer to procedures agreed upon and $\mathrm{R} \$ 122,193.68$ to procedures not agreed upon. However, only $\mathrm{R} \$ 76,884.12$ were reimbursed, with a coverage deficit of $\mathrm{R} \$ 614,194.13$. In $2017, \mathrm{R} \$ 599,998.76$ should have been reimbursed, $\mathrm{R} \$ 485,693.91$ of which for procedures agreed upon and $\mathrm{R} \$ 114.304,85$ for procedures not agreed upon. However, SUS reimbursed only $\mathrm{R} \$ 96,100.11$, with a $\mathrm{R} \$$ 503,898.65 deficit.

The percentage of coverage of SUS nursing procedures, of $11.13 \%$ in 2016 and $16.02 \%$ in 2017, was insufficient to cover the values spent by the UH. In these two years, the financial deficit was $\mathrm{R} \$ 1,118,092.78$ (86.60\% of the measured cost). This deficit, each year, makes it harder for the university to maintain and perform investments in infrastructure and in improvements for its technology complex, since the expenses with procedures by themselves burden the cost of the university with the UH.

The percentage of SUS coverage presented a difference significantly inferior to this study's calculated costs, indicating that the higher the productivity of nursing procedures conducted in the Outpatient facility, the higher was the financial deficit for the Hospital and, consequently, the higher the costs not covered by SUS and assigned to the University, and the difficulties with payment, investment, and renewal of their technology and infrastructure complex, increasingly obsolete and precarious.

Teaching hospitals, due to their role in training qualified professionals and producing new health technologies based on scientific evidence, have no focus on productivity, even though the contract with SES includes this specificity. Health care is not restricted to the production of procedures. It has also a human and integral aspect.

This research shows the actual cost for nursing procedures performed in the political context of UH, i.e., with higher values impacted by the cost of qualified DWF and time spent by the nursing team, which, in their technical competence, care for patients in an integral, individualized, and humane manner, in accordance with their health necessities.

The research on the current form of funding for SUS procedures in UHs reflects criticism on the logic of doing more (production) with less financial resources. Nursing assistance should be guided by qualified care.

\section{RESUMO}

Objetivo: Analisar o percentual de cobertura do repasse do Sistema Único de Saúde relativo aos procedimentos de enfermagem realizados no Ambulatório de um Hospital Universitário. Método: Pesquisa quantitativa, exploratório-descritiva, do tipo estudo de caso. A amostra para o cálculo dos custos médios totais diretos constituiu-se da observação não participante de 656 procedimentos. Os custos obtidos foram comparados com o repasse do Sistema Único de Saúde multiplicando-se a quantidade de procedimentos pactuados pelo custo unitário da Tabela de Procedimentos Unificada nos anos de 2016 e 2017. Resultados: O Sistema Único de Saúde repassou 
percentagem correspondente a 11,13\% do custo real em 2016 e a 16,02 \% em 2017. Nesses dois anos, os valores de repasse cobriram, em média, apenas 13,4\%, resultando numa diferença percentual de receita significantemente inferior aos custos reais. Conclusão: Quanto maior a produtividade dos procedimentos realizados, maior foi o déficit para o Hospital e, consequentemente, maiores foram os custos não cobertos pelo Sistema Único de Saúde.

\section{DESCRITORES}

Assistência Ambulatorial; Cuidados de Enfermagem; Custos e Análise de Custo; Controle de Custos; Custos de Cuidados de Saúde; Sistema Único de Saúde.

\section{RESUMEN}

Objetivo: Analizar el porcentaje de cobertura de las transferencias del Sistema Único de Salud relacionadas con los procedimientos de enfermería realizados en el Ámbulatorio de un Hospital Universitario. Método: Investigación cuantitativa, exploratoria-descriptiva y de tipo estudio de caso. La muestra para el cálculo del total de los promedios de los costos directos consistió en la observación no participativa de 656 procedimientos. Los costos obtenidos se compararon con la transferencia del Sistema Único de Salud multiplicando el número de procedimientos acordados por el costo unitario en la Tabla Unificada de Procedimientos en los años 2016 y 2017. Resultados: El Sistema Único de Salud transmitió un porcentaje correspondiente al 11,13\% del costo real en 2016 y al 16,02\% en 2017. En esos dos años, los valores de transferencia abarcaron, en promedio, sólo el 13,4\%, lo que dio lugar a una diferencia porcentual en los ingresos significativamente inferior a los costos reales. Conclusión: Cuanto mayor fue la productividad de los procedimientos realizados, mayor fue el déficit para el Hospital y, en consecuencia, mayores fueron los costos no cubiertos por el Sistema Unico de Salud.

\section{DESCRIPTORES}

Atención Ambulatoria; Atención de Enfermería; Costos y Análisis de Costo; Control de Costos; Costos de la Atención em Salud; Sistema Único de Salud.

\section{REFERENCES}

1. Zurita RCM, Zurita RM. Gastos ambulatoriais do SUS em serviços auditivos nas macrorreegionais do estado Paraná. Colloquium Vitae. 2014;6(2):59-70. doi: 10.5747/cv.2014.v06.n2

2. Brasil. Decreto Lei n. 7.508, de 28 de julho de 2011. Regulamenta a Lei ${ }^{\circ}$ 8.080, de 19 de setembro de 1990, para dispor sobre a organização do SUS, o planejamento da saúde, a assistência à saúde e a articulação interfederativa, e dá outras providências [Internet]. Brasília; 2011 [citado 2018 set. 09]. Disponível em: https:/www2.camara.leg.br/legin/fed/decret/2011/decreto-7508-28-junho-2011610868-norma-pe.html

3. Brasil. Emenda Constitucional no 29, de 13 de setembro de 2000. Altera os arts. 34, 35, 156, 160, 167 e 198 da Constituição Federal e acrescenta artigo ao Ato das Disposições Constitucionais Transitórias, para assegurar os recursos mínimos para o financiamento das ações e serviços públicos de saúde [Internet]. Brasília; 2000 [citado 2018 set. 09]. Disponível em: http://www.planalto.gov.br/ccivil_03/ constituicao/Emendas/Emc/emc29.htm

4. Brasil. Lei Complementar $n^{\circ} 141$, de 13 de janeiro de 2012. Regulamenta o $\S 3^{\circ}$ do art. 198 da Constituição Federal para dispor sobre os valores mínimos a serem aplicados anualmente pela União, Estados, Distrito Federal e Municípios em ações e serviços públicos de saúde; estabelece os critérios de rateio dos recursos de transferências para a saúde e as normas de fiscalização, avaliação e controle das despesas com saúde nas 3 (três) esferas de governo; revoga dispositivos das Leis n ${ }^{\circ} 8.080$, de 19 de setembro de 1990, e 8.689, de 27 de julho de 1993 [Internet]. Brasília; 2012 [citado 2018 set. 09]. Disponível em: http://www.planalto.gov.br/ccivil_03/leis/lcp/lcp141.htm

5. Silva GS, Colósimo FC, Sousa AG, Piotto RF, Castilho V. coronary artery bypass graft surgery cost coverage by the Brazilian Unified Health System (SUS). Braz J Cardiovasc Surg. 2017;32(4):253-9. doi: http://dx.doi.org/10.21470/1678-9741-2016-0069

6. Lima SML, Rivera FJU. A contratualização nos hospitais de ensino no sistema único de saúde brasileiro. Ciênc Saúde Coletiva. 2012;17(9):2507-21. doi: http://dx.doi.org/10.1590/S1413-81232012000900031

7. Mendes A, Carnut L, Guerra LDS. Reflexões acerca do financiamento federal da Atenção Básica no Sistema Único de Saúde. Saúde Debate. 2018;42(spe1):224-43. doi: https://doi.org/10.1590/0103-11042018S115

8. Saldiva PHN, Veras M. Gastos públicos com saúde: breve histórico, situação atual e perspectivas futuras. Estudos Avançados. 2018;32(92):47-61. doi: https://doi.org/10.5935/0103-4014.20180005

9. Brasil. Ministério da Saúde. DATASUS. Sistema de Gerenciamento da Tabela de Procedimentos, Medicamentos, Órteses, Próteses e Materiais Especiais (SIGTAP, OPM) do SUS [Internet]. Brasília; 2018 [citado 2018 set. 09]. Disponível em: http://sigtap.datasus.gov.br/ tabela-unificada/app/sec/inicio.jsp

10. Universidade de São Paulo, Faculdade de Medicina, Hospital Universitário. Relatório analítico do balanço financeiro do Hospital Universitário da USP. São Paulo: HU; 2018.

11. Bittar E, Castilho V. The cost of transcatheter aortic valve implantation according to different access routes. Rev Esc Enferm USP. 2017;51:e03246. doi: http://dx.doi.org/10.1590/S1980-220X2016050503246

12. Hsiao J, Lima AFC. Custo direto da hemodiálise em unidade de terapia intensiva adulto. Cogitare Enferm. 2015;20(4):675-83. doi: http:// dx.doi.org/10.5380/ce.v20i4.41782

13. Silva RS, Haddad MCL, Rossaneis MA, Gois MFF. Análise financeira das internações de diabéticos submetidos à amputação de membros inferiores em hospital público. Semina Cien Biol Saúde (Londrina). 2015;36(1 Supl.):81-8. doi: 10.5433/1679-0367.2014v35n2p81

14. Castilho V, Lima AFC, Fugulin FMT. Gerenciamento de custos nos serviços de Enfermagem. In: Kurcgant $\mathrm{P}$, coordenadora. Gerenciamento em enfermagem. $3^{\text {a }}$ ed. Rio de Janeiro: Guanabara Koogan; 2016. p.170-83.

15. Oliveira DF. A implantação de um sistema de gestão de custos no hospital universitário pela EBSERH: um estudo de caso com utilização do PMBOK. Rev Adm Hosp Inov Saúde. 2016;13(3):122-39. doi: https://doi.org/10.21450/rahis.v13i3.3172

16. Lima AFC. Direct costs of integrated procedures of conventional hemodialysis performed by nursing professionals. Rev Latino Am Enfermagem. 2018;26:e2944. doi: http://dx.doi.org/10.1590/1518-8345.1812.2944 
17. Brasil. Ministério da Saúde, Conselho Nacional de Saúde. Resolução n. 466, de 12 de dezembro de 2012. Dispõe sobre diretrizes e normas regulamentadoras de pesquisas envolvendo seres humanos [Internet]. Brasília; 2012 [citado 2018 out. 10]. Disponível em: https:// conselho.saude.gov.br/resolucoes/2012/Reso466.pdf

18. Bel Homo RF, Lima AFC. Direct cost of maintenance of totally implanted central venous catheter patency. Rev Latino Am Enfermagem. 2018;26:e3004. doi: 10.1590/1518-8345.2263.3004

19. Gouvêa AL, Lima AFC. Direct cost of connecting, maintaining and disconnecting patient-controlled analgesia pump. Rev Esc Enferm USP. 2014;48(1):104-9. doi: 10.1590/S0080-623420140000100013

20. Gil RB, Chaves LDP, Laus AM. Gerenciamento de recursos materiais com enfoque na queixa técnica. Rev Eletr Enf. 2015;17(1):100-7. doi: $10.5216 /$ ree.v171.27544

21. Souza AA, Xavier AG, Lima LCM, Guerra M. Análise de custos em hospitais: comparação dos custos de procedimentos de urologia e os valores repassados pelo Sistema Único de Saúde. Rev ABCustos. 2013;8(1):90-107 doi: https://doi.org/10.47179/abcustos.v8i1.331

22. Jesus CTE, Goularte JLL, Ramos TJF, Flores SAM. Apuração de custos da patologia acidente vascular cerebral em um hospital filantrópico. Rev Audit Gov Contabil [Internet]. 2015 [citado 2018 set. 09];3(8):33-46. Disponível em: http://www.fucamp.edu.br/editora/index.php/ ragc/article/view/618

23. Bezerra SMG, Luz MHBA, Andrade EMLR, Araújo TME, Teles JBM, Caliri MHL. Prevalência, fatores associados e classificação de úlcera por pressão em pacientes com imobilidade prolongada assistidos na Estratégia Saúde da Família. Estima [Internet]. 2014 [citado 2018 jun. 15];12(3). Disponível em: https://www.revistaestima.com.br/index.php/estima/article/view/95

24. Pires MBN, Oliveira R, Alcântara CCV, Abbas K. A relação entre a remuneração do Sistema Único de Saúde, os custos dos procedimentos hospitalares e o resultado: estudo nas Santas Casas de Misericórdia do Estado de São Paulo. Rev Adm Hosp Inov Saúde. 2017;14(3). doi: https://doi.org/10.21450/rahis.v14i3.4286

25. Miranda GMD, Mendes ACG, Silva ALA. O desafio da organização do sistema único de saúde universal e resolutivo no pacto federativo brasileiro. Saúde Soc. 2017;26(2):329-35. doi: https://doi.org/10.1590/S0104-12902017168321

26. Castro LC, Castilho V. The cost of waste of consumable materials in a surgical center. Rev Latino Am Enfermagem. 2013;21(6):1228-34. doi: 10.1590/0104-1169.2920.2358

27. Entringer AP, Pinto MFT, Gomes MASM. Análise de custos da atenção hospitalar ao parto vaginal e à cesariana eletiva para gestantes de risco habitual no Sistema Único de Saúde. Ciênc Saúde Coletiva. 2019;24(4):1527-36. doi: https://doi.org/10.1590/141381232018244.06962017

28. Oliveira RR, Melo EC, Novaes ES, Ferracioli PLRV, Mathias TAF. Factors associated to Caesarean delivery in public and private health care systems. Rev Esc Enferm USP. 2016;50(5):733-40. doi: https://doi.org/10.1590/s0080-623420160000600004

29. Entringer AP, Pinto M, Dias MAB, Gomes MASM. Análise de custo-efetividade do parto vaginal espontâneo e da cesariana eletiva para gestantes de risco habitual no Sistema Único de Saúde. Cad Saúde Pública. 2018;34(5):e00022517. doi: https://doi.org/10.1590/0102$311 \times 00022517$

30. Massuda A, Hone T, Leles FAG, Castro CC, Atun R. The Brazilian health system at crossroads: progress, crisis and resilience. BMJ Global Health, 2018;3:e000829. doi: 10.1136/bmjgh-2018-000829

31. Renmans D, Criel NHB, Meessen B. Performance-based financing: the same is different. Health Policy Plan. 2017;32(6):8608. doi: https:// doi.org/10.1093/heapol/czx030

Financial support

Conselho Nacional de Desenvolvimento Científico e Tecnológico (CNPq). 